\section{Oppdatert om nevrodegenerative sykdommer}

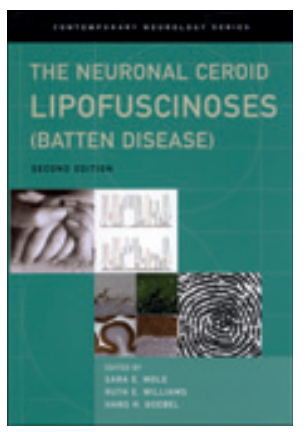

Sara E. Mole, Ruth E. Williams,

Hans H. Goelbel, red.

The neuronal ceroid lipfuscinosies

(Batten disease)

444 s, tab, ill. Oxford: Oxford University Press,

2011. Pris GBP 90

ISBN 978-0-19-959001-8

Denne utgivelsen er en oppdatert oversikt over nevronale ceroide lipofuscinoser (NCL), definert som en progredierende degenerativ sykdom i hjernen og, i de fleste tilfeller, retina, forbundet med intracellulær avleiring av materiale som morfologisk kan karakteriseres som ceroid lipofuscin. Målgruppen er barneleger, nevrologer, genetikere og patologer. Til sammen 81 forfattere har bidratt til de 22 kapitlene. Til tross for mange bidragsytere har redaktørene sørget for at komposisjonen er enhetlig. Kapitlene om de enkelte NCL-sykdommene er bygd over samme lest: introduksjon, molekylærbiologi, cellebiologi, kliniske data, morfologi, sykdomsmekanisme, genotype- og fenotypevariasjoner, diagnose og behandling.

NCL-sykdommene har tradisjonelt hatt en numerisk benevning etter debutalder, f.eks. NCL1 ved infantil debut, NCL2 ved seninfantil debut etc. En ny klassifikasjon konstruert omkring navnet på genet presenteres. NCL1 heter nå CLN1-sykdom, etterfulgt av alder ved debut (infantil, sen-infantil, juvenil eller adult). Som nordmenn kan vi være stolte av at det er gitt plass til en faksimile av den første beskrivelsen av nevronale ceroide lipofuscinoser, nemlig berglege Stengels Beretning om et markeligt Sygdomstilfalde hos fire Sødskende, som han publiserte i tidsskriftet Eyr i 1826 (1). Sykdommen som Stengel beskrev, heter nå verken Spielmeyer-Vogt eller Batten, men CLN3-sykdom, klassisk juvenil. Hvor lett det blir å avskaffe gammel nomenklatur, gjenstår å se.

Et annet formål med klassifikasjonen er å dele genproduktene inn i enzymer eller ikke-enzymer, da førstnevnte gruppe er best egnet for behandling. I kapitlet om behandling gir forfatterne en grei oppsummering av potensielle strategier med gyldighet for nesten alle genetisk betingede nevrodegenerative sykdommer. Her har vitenskapen kommet kort, selv om forfatterne viser til enkelte oppmuntrende resultater i genetisk modifiserte musemodeller.

Mange av illustrasjonene ville nok vært mer spennende om de var blitt trykt i sine originale farger. For leger og forskere som steller med nevrodegenerative sykdommer, er det vanskelig å komme utenom denne boken.

\section{Petter Strømme}

Barnesenteret

Oslo universitetssykehus, Ullevål

\footnotetext{
Litteratur

1. Brean A. Beretning om et mærkeligt Sygdomstilfælde - Stengel-Batten-Spielmeyer-Vogts sykdom. Tidsskr Nor Lægeforen 2004; 124: 970-1.
}

\section{Leseverdig om oppmerksomhetstrening}

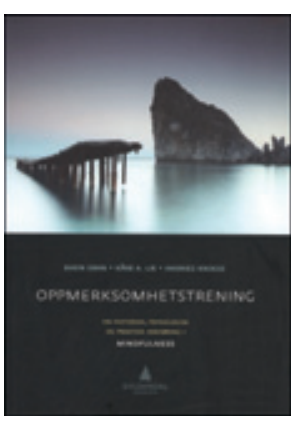

Svein Gran, Kåre A. Lie, Andries Kroese Oppmerksomhetstrening

En historisk, psykologisk og praktisk innføring i mindfulness. 208 s, tab, ill. Oslo: Gyldendal Akademisk, 2011. Pris NOK 315 ISBN 978-82-05-41573-7

Målgruppen er alle som er interessert i å vite mer om oppmerksomhetstrening (mindfulness), men boken egner seg nok best for ansatte i helsevesenet og helsefagstudenter som ønsker å sette seg inn i dette raskt voksende fagfeltet.

Forfatterne innleder med en oversikt over det eksponentielt økende antall medisinske artikler om temaet. Dernest er det en gjennomgang av røttene til oppmerksomhetstrening innen buddhismen for 2500 år siden. Vi følger så en av forfatternes spennende, personlige reise i hans eksistensielle utforsking av temaet og lærdommen som han høster gjennom møter med ulike østlige og vestlige meditasjonslærere. Deretter følger vi utviklingen og erfaringene med et stressmestringskurs i oppmerksomhetstrening ved et distriktspsykiatrisk senter. Etter dette er det tre kapitler hvor forfatterne går gjennom oppmerksomhetstrening innen medisin, kognitiv terapi og psykodynamisk (psykoanalytisk) terapi. Så kommer en praktisk gjennomgang av de sentrale øvelsene som benyttes i oppmerksomhetstrening, og en oppsummering av kjernepunkter fra alle kapitlene. Til slutt er det to vedlegg, ett om oversettelse av kjernebegreper fra det opprinnelige språket pali til norsk, og ett om hvordan begrepet oppmerksomhetstrening blir definert av sentrale nålevende forskere innen feltet.

Boken er godt komponert, meget leseverdig og egner seg utmerket som en grundig innføringsbok. Spesielt synes jeg at kapitlene om oppmerksomhetstrening og kognitiv og psykodynamisk terapi er meget innsiktsfulle.

Når forfatterne går gjennom det opprinnelige vestlige kurskonseptet i oppmerksomhetstrening, Mindfulness-Based Stress Reduction ved John KabatZinn, kunne de vært grundigere i omtalen av bakgrunnen for valg av temaer og rekkefølgen for når de ulike typene øvelsene blir introdusert. Her finnes det imidlertid mye annen tilgjengelig litteratur. Videre ville det vært en fordel om begrepsbruken av et sentralt tema i oppmerksomhetstrening, nemlig sinnet, var blitt behandlet mer enhetlig av forfatterne.

Innvendingene blir likevel detaljer, og jeg nøler ikke med å anbefale alle med interesse for sammenhengen mellom psyke og soma, mellom helse og uhelse, mellom lidelse og livskvalitet, å lese boken.

Michael de Vibe

Nasjonalt kunnskapssenter for helsetjenesten 